\title{
Dietary Protein to Metabolizable Energy Ratios on Feed Efficiency and Structural Growth of Prepubertal Holstein Heifers ${ }^{1}$
}

\author{
M. T. Gabler ${ }^{2}$ and A. J. Heinrichs \\ Department of Dairy and Animal Science \\ The Pennsylvania State University, \\ University Park, PA 16802
}

\section{ABSTRACT}

Sixty Holstein heifers, $124.5 \pm 1.1 \mathrm{~d}$ of age and 124.9 $\pm 2.5 \mathrm{~kg}$ of $\mathrm{BW}$, were used to evaluate the influence of dietary crude protein to metabolizable energy ratio (CP:ME) on feed efficiency, structural growth, and body condition score. Treatment rations containing a specific $\mathrm{CP}: \mathrm{ME}$ ratio were assigned to heifers in a complete randomized block design with treatment periods lasting 20 wk. The CP:ME ratios were 48.3, 59.1, 67.5, and $76.5 \mathrm{~g}$ of $\mathrm{CP}$ per Mcal of ME. The CP:ME ratios were altered by adjusting the concentration of $\mathrm{CP}(12.0,15.2$, 17.4 , and $19.7 \% \mathrm{CP})$ with similar amounts of ME (2.6 $\mathrm{Mcal} / \mathrm{kg} \mathrm{DM}$ ) across all treatment rations. BW was recorded weekly on two consecutive days and used to adjust dry matter intake to allow approximately 0.80 $\mathrm{kg} / \mathrm{d}$ gain. Average daily gain did not differ between the treatment rations, $0.74,0.81,0.81,0.77 \mathrm{~kg} / \mathrm{d}$, low to highest CP:ME ratio, respectively. Dry matter intake showed a quadratic effect for the treatment rations, $3.30,3.41,3.48$, and $3.39 \mathrm{~kg} / \mathrm{d}$, low to highest CP:ME ratio, respectively, and averaged $2.0 \%$ BW. Feed efficiency improved linearly with increasing CP:ME ratios, $4.76,4.42,4.35$, and 4.33 , respectively. The increased $\mathrm{CP}: \mathrm{ME}$ ratios were accompanied by increasing levels of plasma urea $\mathrm{N}, 9.88,13.34,14.94$, and $16.57 \mathrm{mg} / \mathrm{dl}$, respectively. A trend toward linear increases in wither and hip height growth resulted with increasing CP:ME. Hip width growth was quadratic with increasing CP:ME ratios. Observed linear effects in feed efficiency and some structural growth measurements demonstrate positive results when feeding CP:ME ratios $>48.3$ to Holstein heifers between 125 and $234 \mathrm{~kg}$ of BW and gaining $0.80 \mathrm{~kg} / \mathrm{d}$.

(Key words: heifer growth, protein energy ratio, feed efficiency)

Received November 14, 2002.

Accepted August 9, 2002.

Corresponding author: A. J. Heinrichs; e-mail: ajh@psu.edu.

${ }^{1}$ This research was a component of NC-119, Dairy Herd Management Strategies for Improved Decision Making and Profitability.

${ }^{2}$ Current address: ADM Alliance Nutrition, P.O. Box 44307, Madison, WI.
Abbreviation key: ADG = average daily gain, $\mathbf{C P : M E}$ $=$ crude protein to metabolizable energy ratio, $\mathbf{F E}=$ feed efficiency, $\mathbf{M E}=$ metabolizable energy, $\mathbf{P U N}=$ plasma urea nitrogen.

\section{INTRODUCTION}

Efficient utilization of dietary $\mathrm{CP}$ and energy yielding nutrients by prepubertal Holstein heifers can minimize rearing costs and maximize herd life productivity. Preston (1966) first made note of the synergism between protein and energy by reporting that protein requirements for young ruminants have little meaning unless energy requirements have been satisfied.

Odham (1984) states the interrelationship between protein and energy within the rumen and within the ruminant body can have tremendous effects on the overall pattern of nutrient use. Numerous studies (Bagg et al., 1985; Kertz et al., 1987; Radcliff et al., 1997; and Van Amburgh et al., 1998) have evaluated dietary protein and energy on Holstein prepubertal heifer growth, yet few have evaluated protein and energy together as a relationship, such as a ratio (CP:ME). Schurman and Kesler (1974) evaluated CP:ME ratios (49.3, 52.2, and $89.7 \mathrm{~g}$ of CP per Mcal of ME) in ruminating dairy calves, 74 to $142 \mathrm{~kg}$ of BW. The lowest CP:ME ratios, 49.3 and 52.2 , resulted in superior growth and feed efficiency (FE), while the 49.3 CP:ME ratio improved ration digestibility and $\mathrm{N}$ utilization (Schurman and Kesler, 1974).

Recently, Lammers and Heinrichs (2000) revisited the concept of CP:ME ratios on growth of prepubertal heifers, 200 to $341 \mathrm{~kg}$ of BW. Lammers and Heinrichs (2000) set daily energy intake at $16 \mathrm{Mcal}$ of ME with the amount of dietary $\mathrm{CP}$ altered to achieve the desired ratio of CP:ME, 46.3, 54.2, and 60.9, respectively. Dry matter intake was restricted at $2.45 \% \mathrm{BW}$ of heifers with results showing heifers consuming the highest CP:ME ratio, 60.9, possessed the highest rate of gain, FE, structural growth, and growth of mammary ductal development through indirect measurement (Lammers and Heinrichs, 2000). 
Results by Schurman and Kesler (1974) and Lammers and Heinrichs (2000) reported that balancing CP and $\mathrm{ME}$ results in optimum utilization of nutrients and growth in prepubertal heifers, 74 to $142 \mathrm{~kg}$ of BW and 200 to $341 \mathrm{~kg}$ of BW, respectively. No published information is available on CP:ME ratios' effects on growth of prepubertal Holstein heifers between 142 and 200 $\mathrm{kg}$ of BW. Superior CP:ME ratios in the studies by Schurman and Kesler (1974) and Lammers and Heinrichs (2000) of 49.3 and 60.9, respectively, achieved rates of gain of approximately $1.0 \mathrm{~kg} / \mathrm{d}$, which have been shown to negatively affect first lactation milk production (Van Amburgh et al., 1998; Lammers et al., 1999). The objective of the study was to determine a CP:ME ratio for $0.80 \mathrm{~kg} / \mathrm{d}$ rate of gain that allows efficient conversion of feed to lean tissue and maximizes structural growth in prepubertal Holstein heifers between 125 and $234 \mathrm{~kg}$ of BW.

\section{MATERIALS AND METHODS}

Sixty Holstein heifers at $110 \mathrm{~d}$ of age were trained to use Calan feeding doors, with heifers consuming an adaptation diet for $14 \mathrm{~d}$ before the treatment period. Heifers were housed in a naturally ventilated barn with bedding pack space maintained at $3.7 \mathrm{~m}^{2}$ per heifer. During the adaptation period, heifers were fed a ration meeting NRC (1989) recommendations for $0.80 \mathrm{~kg} / \mathrm{d}$ average daily gain (ADG) and estimated to contain a CP:ME ratio of $50.0 \mathrm{~g}$ of CP per Mcal ME. At $124.5 \pm$ $7.8 \mathrm{~d}$ of age and $124.9 \pm 2.5 \mathrm{~kg}$ of BW, heifers were randomly assigned to one of four treatment rations in a randomized complete block design. Heifers were blocked according to age with treatment rations imposed for $140 \mathrm{~d}$. The treatment rations were determined to contain CP:ME ratios of 48.3, 59.1, 67.5, and $76.5 \mathrm{~g}$ of CP per Mcal ME. The CP:ME ratios were altered by adjusting the concentration of dietary $\mathrm{CP}(12.0,15.2$, 17.4 , and $19.7 \% \mathrm{CP}$ ) with similar amounts of $\mathrm{ME}$ (NRC, 1996; $2.6 \mathrm{Mcal}$ of $\mathrm{ME} / \mathrm{kg}$ of DM) across all treatment rations. Treatment rations contained corn silage and grass hay as forage sources with supplemental soybean meal as the major protein source. Treatment rations were formulated to provide a 60 to 40 forage-to-concentrate ratio.

The quantity of treatment ration offered to each heifer was adjusted weekly in an attempt to achieve an ADG of $0.80 \mathrm{~kg} / \mathrm{d}$. The quantity of treatment ration offered was adjusted as a percentage of BW as DMI. Weekly BW was recorded on two consecutive days 3 $\mathrm{h}$ postfeeding to determine the quantity of treatment ration offered for the next $7 \mathrm{~d}$. Any daily treatment ration refusal was weighed and recorded.
Samples of treatment rations and forages were collected $3 \times$ wk. Portions of the weekly treatment ration samples and forages were dried at that time for determination of treatment ration and forage DM with adjustment of treatment rations to achieve accurate daily DMI as a percentage of BW. The remaining portions of the treatment ration samples were frozen $\left(-20^{\circ} \mathrm{C}\right)$ until compositing every $21 \mathrm{~d}$ to determine particle size (Lammers et al., 1996), DM, CP (AOAC, 1990), soluble CP (Krishnamoorthy et al., 1982), RDP (Krishnamoorthy et al., 1983), total NSC (Smith, 1981; modified to use ferricyanide as a calorimetric indicator), starch (Holm et al., 1986), sugar (Dubois et al., 1956), and NDF and ADF (ANKOM ${ }^{200}$ Fiber Analyzer, ANKOM Technology Corporation, Fairport, NY). The remaining portions of the forage samples were frozen $\left(-20^{\circ} \mathrm{C}\right)$ until compositing every $21 \mathrm{~d}$ for determination of $\mathrm{DM}, \mathrm{CP}, \mathrm{NDF}$, and ADF.

Wither height, hip height, hip width, heart girth, and BCS (based on a 5-point scale, 1 = under-conditioned, and $5=$ over-conditioned) were recorded $3 \mathrm{~h}$ postfeeding at the beginning and every $28 \mathrm{~d}$ until the end of the treatment period. Blood samples were also taken at these 28-d intervals. Blood was acquired from the left jugular vein via venipuncture with Vacutainer tubes. Plasma samples were aspirated after centrifugation $(4000 \times g)$ and frozen $\left(-20^{\circ} \mathrm{C}\right)$ for later analysis. Plasma samples were analyzed for urea N (procedure no. 0580; Stanbio Laboratory, Inc., San Antonio, TX).

\section{Statistical Analysis}

Nutrient content of treatment rations were analyzed by the PROC GLM procedure of SAS (1985). The following model was used:

$$
\mathrm{Y}_{\mathrm{i}}=\mu+\mathrm{d}_{\mathrm{i}}+\mathrm{e}_{\mathrm{i}}
$$

where $Y_{i}$ is the observation for the ith treatment ration, $\mu$ is the overall mean, $d_{i}$ is the fixed effect of the ith treatment ration, and $e_{i}$ is the normally identical and independently distributed error term. Least square means and standard errors were determined using the LSMEANS and STDERR statement in PROC GLM. Mean separations were determined using the PDIFF statement in PROC GLM.

The design of the experiment was a randomized complete block with four treatment rations. Initial age, initial and final BW, initial and final measurements for wither height, hip height, hip width, heart girth, and BCS were analyzed in a block design by PROC GLM. The following model was used:

Journal of Dairy Science Vol. 86, No. 1, 2003 


$$
\mathrm{Y}_{\mathrm{ij}}=\mu+\rho_{\mathrm{i}}+\mathrm{d}_{\mathrm{j}}+\mathrm{e}_{\mathrm{ij}}
$$

where $Y_{i j}$ is the observation for the ith treatment ration within the ith block, $\mu$ is the overall mean, $\rho_{\mathrm{i}}$ is the fixed effect of the ith block, $d_{j}$ is the fixed effect of the $j$ th treatment ration, and $e_{i j}$ is the normally identical and independently distributed error term. Least square means and standard errors were determined using the LSMEANS and STDERR statement in PROC GLM. Orthogonal contrasts for linear, quadratic, and cubic effects of the treatment rations were determined using the ESTIMATE statement in PROC GLM.

Average daily gain, DMI, DMI as a percentage of BW, $\mathrm{FE}$, growth rate for wither height, hip height, hip width, heart girth, change in BCS, and plasma urea N (PUN) were analyzed with repeated measurements at 0,28 , $56,84,112$, and $140 \mathrm{~d}$ by the PROC MIXED procedure of SAS (Littell et al., 1996). The following model was used:

$$
\mathrm{Y}_{\mathrm{ijk}}=\mu+\rho_{\mathrm{i}}+\mathrm{d}_{\mathrm{j}}+\lambda_{\mathrm{k}}+\beta\left(\mathrm{x}_{\mathrm{ijk}}-\mathbf{x}\right)+\mathrm{e}_{\mathrm{ijk}}
$$

where $\mathrm{Y}_{\mathrm{ijk}}$ is the observation for the jth treatment ration within the ith block at the kth measurement, $\mu$ is the overall mean, $\rho_{\mathrm{i}}$ is the fixed effect of the ith block, $\mathrm{a}_{\mathrm{i}}$ is the fixed effect of the jth treatment ration, $\lambda_{\mathrm{k}}$ is the fixed effect of the kth measurement, $\beta$ is the coefficient relating the covariance of the response variable, $\mathrm{x}_{\mathrm{ijk}}$ is the covariance for the jth treatment ration within the ith block at the kth measurement, and $\mathrm{e}_{\mathrm{ijk}}$ is the normally identical and independently distributed error term. Least square means and standard errors for ADG, structural growth rates, and BCS change were determined by SLOPE using the ESTIMATE statement in PROC MIXED at the 140-d time point. Least square means and standard errors for DMI, FE, and PUN were determined using LSMEANS in PROC MIXED at the 140-d time point. Orthogonal contrasts for linear, quadratic, and cubic effects of the treatment rations were determined using the ESTIMATE statement in PROC MIXED.

A heterogeneous autoregressive one covariance structure was utilized in analysis of ADG and DMI. A factorial analysis one covariance structure was utilized in analysis of DMI as a percentage of BW, FE, and PUN. An autoregressive moving average one covariance structure was utilized for analysis of changes in structural growth and BCS. Interactions for treatment ration and time was not significant for any of the parameters except for PUN where a treatment ration $\times$ time interaction, a treatment ration $\times$ time $\times$ time interaction, and a time $\times$ time interaction existed. All significant differences were for $(P \leq 0.05$.

\section{RESULTS AND DISCUSSION}

Ingredient and nutrient composition of the treatment rations are located in Table 1 . Treatment ration $\mathrm{CP}$ increased incrementally, whereas ME calculated from TDN remained constant by design. Soluble CP and $\mathrm{RDP}$, as a percentage of dietary $\mathrm{CP}$, were similar across treatment rations. The lowest CP:ME ratio, 48.3, possessed differences in DM, 8- to 19-mm particle size, less than 8-mm particle size, NDF, and ADF despite similar forage components compared with other treatment rations. These differences were primarily the result of soyhulls in the 48.3 CP:ME ratio treatment ration.

Heifers began consuming the treatment rations at $124.5 \pm 1.1 \mathrm{~d}$ of age and $124.9 \pm 2.5 \mathrm{~kg}$ of BW (Table 2 ). Average daily gain (Table 2), as determined through analysis of change in BW, showed no effects between treatment rations. While the 48.3 and 76.5 CP:ME ratios possessed slightly lower ADG than the preplanned $0.80 \mathrm{~kg} / \mathrm{d}$ rate of gain, no orthogonal effects were determined. Final measurements of BW (Table 2) also showed no orthogonal effects. Evaluation of treatment rations, intake, and ingredient compositions (Table 1), using the Dairy Cattle Model (NRC, 2001) reported on average $32.8 \%$ less energy allowable gains than the rates of gain actually observed in the current study $(38.9,35.6,31.2,25.0 \%$ less energy allowable gains with increasing CP:ME ratios, respectively). Metabolizable energy required for the observed rates of gain provided by the Dairy Cattle Model (NRC, 2001) were, on average, $13.1 \%$ greater than required to achieve the observed rates of gain in the current study $(18.66,12.4$, $9.7,11.7 \%$ greater required $\mathrm{ME}$ values with increasing CP:ME ratios, respectively).

Dry matter intake (Table 2) was adjusted as a percentage of BW weekly after two consecutive weight measurements, $3 \mathrm{~h}$ postfeeding. Dry matter intake showed a quadratic effect. Dry matter intake as a percentage of BW (Table 2) showed no orthogonal effects, which resulted from a set rate of gain and restricted intake, and averaged 2.0\% BW as DMI. Heifers receiving 2.0\% BW as DMI have achieved similar rates of gains in studies by Meinert et al. (1992) and Swartz et al. (1991). It was visually observed with feeding rates at $2.0 \%$ BW as DMI, rapid consumption of the entire treatment rations occurred within $3 \mathrm{~h}$. Consumption of feed in this manner most certainly has effects on rumen fermentation, digestion, and nutrient utilization.

Given the DMI values presented in Table 2, daily CP intake, ME intake, and CP:ME ratios are calculated in Table 3. The present study was conducted between January 1999 and April 2000. Thus treatment rations were designed based on NRC 1989 requirements and are included in Table 3 along with the NRC 2001 re- 
Table 1. Ingredient and nutrient compositions of the treatment rations (DM basis).

\begin{tabular}{|c|c|c|c|c|c|}
\hline \multirow[b]{2}{*}{ Composition } & \multicolumn{4}{|c|}{$\begin{array}{c}\text { Dietary CP to Metabolizable energy ratios } \\
\text { (g CP per Meal ME) }\end{array}$} & \multirow[b]{2}{*}{$\mathrm{SE}$} \\
\hline & 48.3 & 59.1 & 67.5 & 76.5 & \\
\hline \multicolumn{6}{|l|}{ Ingredients, \% } \\
\hline Corn silage $^{1}$ & 34.4 & 34.4 & 34.4 & 32.4 & - \\
\hline Grass hay $^{2}$ & 25.6 & 25.6 & 25.6 & 25.6 & - \\
\hline Soybean meal & 8.2 & 9.1 & 15.8 & 21.5 & - \\
\hline Cracked dry corn & 17.7 & 14.0 & 10.9 & 9.0 & - \\
\hline Wheat midds & - & 8.7 & 6.8 & 5.6 & - \\
\hline Distillers corn grain & - & 6.5 & 5.1 & 4.2 & - \\
\hline Soyhulls & 11.8 & - & - & - & - \\
\hline Mineral mix $\mathrm{A}^{3}$ & - & 1.7 & 1.2 & 1.2 & - \\
\hline Mineral mix $\mathrm{B}^{4}$ & 2.0 & - & - & - & - \\
\hline Urea & 0.3 & - & 0.2 & 0.3 & - \\
\hline Limestone & - & - & - & 0.2 & - \\
\hline \multicolumn{6}{|l|}{ Nutrients $^{5}$} \\
\hline $\mathrm{DM} \%$ & $60.8^{\mathrm{a}}$ & $57.2^{\mathrm{b}}$ & $57.2^{\mathrm{b}}$ & $58.4^{\mathrm{a}}$ & 1.45 \\
\hline $\mathrm{CP} \%$ & $12.0^{\mathrm{a}}$ & $15.2^{\mathrm{b}}$ & $17.4^{\mathrm{c}}$ & $19.7^{\mathrm{d}}$ & 0.15 \\
\hline Soluble $\mathrm{CP}, \%$ of $\mathrm{CP}$ & 33.5 & 31.3 & 34.8 & 31.8 & 1.60 \\
\hline $\mathrm{RDP}, \%$ of $\mathrm{CP}$ & 66.4 & 67.9 & 66.6 & 67.6 & 1.77 \\
\hline NSC, \% & 32.3 & 32.4 & 31.3 & 30.6 & 0.80 \\
\hline Starch, \% & 19.9 & 19.5 & 19.1 & 19.1 & 0.59 \\
\hline Sugar, \% & 4.5 & 4.4 & 4.0 & 4.9 & 0.33 \\
\hline $\mathrm{NDF}, \%$ & $43.9^{\mathrm{a}}$ & $40.5^{\mathrm{b}}$ & $39.9^{\mathrm{b}}$ & $39.5^{\mathrm{b}}$ & 0.67 \\
\hline $\mathrm{ADF}, \%$ & $27.5^{\mathrm{a}}$ & $23.5^{\mathrm{b}}$ & $23.6^{\mathrm{b}}$ & $23.0^{\mathrm{b}}$ & 0.52 \\
\hline TDN, \% & 68.9 & 71.1 & 71.1 & 71.3 & - \\
\hline $\mathrm{ME},{ }^{7} \mathrm{Mcal} / \mathrm{kg} \mathrm{DM}$ & 2.5 & 2.6 & 2.6 & 2.6 & - \\
\hline \multicolumn{6}{|l|}{ Particle Size } \\
\hline$>19$ mm, \% & 11.6 & 12.4 & 11.5 & 11.6 & 0.89 \\
\hline 8 to $19 \mathrm{~mm}, \%$ & $33.3^{\mathrm{a}}$ & $49.0^{\mathrm{b}}$ & $46.0^{\mathrm{b}, \mathrm{c}}$ & $43.4^{\mathrm{c}}$ & 1.14 \\
\hline$<8 \mathrm{~mm}, \%$ & $55.1^{\mathrm{a}}$ & $38.6^{\mathrm{b}}$ & $42.4^{\mathrm{b}}$ & $45.1^{\mathrm{c}}$ & 1.32 \\
\hline
\end{tabular}

a,b,c,d Superscripts that differ are significant at $P \leq 0.05$.

${ }^{1}$ Corn silage contained $37.6 \% \mathrm{DM}, 39.2 \% \mathrm{NDF}, 23.5 \% \mathrm{ADF}$, and $7.2 \% \mathrm{CP}$ on DM basis.

${ }^{2}$ Grass hay contained $93.1 \% \mathrm{DM}, 68.8 \% \mathrm{NDF}, 40.2 \% \mathrm{ADF}$, and $6.8 \% \mathrm{CP}$ on DM basis.

${ }^{3}$ Contained 41.4 aragonite, 21.9 urea, 14.6 salt, 7.3 magnesium oxide, 4.8 of vitamin E, 4.8 dicalcium phosphate, 2.4 anemia mix, 2.4 selenium (" $0.06 \%$ Se"), 0.9 dynamate ( $22 \mathrm{~S}$ ), and 0.7 of vitamin $\mathrm{ADE}$ as a percentage DM basis.

${ }^{4}$ Contained 38.7 dicalcium phosphate, 23.9 aragonite, 11.7 salt, 7.9 dynamate $22 \mathrm{~S}, 7.9$ magnesium oxide, 5.8 of vitamin E, 3.2 selenium, "0.06\% Se," and 0.9 of vitamin ADE as a percentage of DM basis.

${ }^{5} \mathrm{n}=19$ composite samples representing 171 samples per treatment ration taken during the trial.

${ }^{6}$ Calculated from ingredients.

${ }^{7}$ Estimated: Metabolizable energy $(\mathrm{ME})=\mathrm{TDN} * 0.04409 * 0.82$.

Table 2. Least square means for age, BW, intake, and performance of Holstein heifers fed increasing ratios of dietary CP to metabolizable energy from 125 to $234 \mathrm{~kg}$ of BW.

\begin{tabular}{|c|c|c|c|c|c|c|c|c|}
\hline & \multicolumn{4}{|c|}{$\begin{array}{c}\text { Dietary CP to metabolizable energy ratios } \\
\text { (g CP per Mcal ME) }\end{array}$} & \multirow[b]{2}{*}{$\mathrm{SE}$} & \multicolumn{3}{|c|}{ Contrast $(P)$} \\
\hline & 48.3 & 59.1 & 67.5 & 76.5 & & Linear & Quadratic & Cubic \\
\hline Initial age, d & 124.67 & 123.40 & 125.07 & 124.73 & 2.18 & 0.85 & 0.83 & 0.61 \\
\hline Initial BW, kg & 125.29 & 122.44 & 127.43 & 124.44 & 3.75 & 0.88 & 0.98 & 0.35 \\
\hline Final BW, kg & 227.88 & 235.21 & 240.71 & 231.88 & 7.61 & 0.61 & 0.29 & 0.72 \\
\hline $\mathrm{ADG}, \mathrm{g} / \mathrm{d}$ & 736.50 & 807.86 & 814.16 & 773.87 & 30.74 & 0.58 & 0.32 & 0.33 \\
\hline DMI, kg/d & 3.30 & 3.41 & 3.48 & 3.39 & 0.10 & 0.36 & 0.04 & 0.88 \\
\hline DMI, \% BW & 1.97 & 1.98 & 1.95 & 2.00 & 0.03 & 0.77 & 0.59 & 0.26 \\
\hline $\mathrm{FE}^{1}$ & 4.76 & 4.42 & 4.35 & 4.33 & 0.17 & 0.02 & 0.82 & 0.65 \\
\hline PUN, mg/dl & 9.88 & 13.34 & 14.94 & 16.57 & 0.76 & 0.01 & 0.21 & 0.56 \\
\hline
\end{tabular}

${ }^{1}$ Feed efficiency; expressed as the ratio of $\mathrm{kg}$ of feed to $\mathrm{kg}$ of gain. 
Table 3. Least square means for DMI, CP intake, calculated ME intake, calculated CP:ME ratios, and calculated NSC:RDP ratios.

\begin{tabular}{lccrrrr}
\hline & \multicolumn{7}{c}{ Dietary CP to metabolizable energy ratios } \\
& \multicolumn{7}{c}{ (g CP per Mcal ME) } \\
\cline { 2 - 7 } & $1989 \mathrm{NRC}^{1}$ & $2001 \mathrm{NRC}^{2}$ & \multicolumn{1}{c}{48.3} & 59.1 & 67.5 & 76.5 \\
\hline $\mathrm{DMI}, \mathrm{kg} / \mathrm{d}$ & 4.58 & 4.80 & 3.30 & 3.41 & 3.48 & 3.39 \\
$\mathrm{CP}, \mathrm{g} / \mathrm{d}$ & 700.20 & $710.40^{3}$ & 396.64 & 517.93 & 603.91 & 669.15 \\
$\mathrm{ME},{ }^{4} \mathrm{Mcal} / \mathrm{d}$ & 11.73 & 11.00 & 8.22 & 8.76 & 8.94 & 8.74 \\
Ratio CP:ME & 59.70 & 64.58 & 48.28 & 59.12 & 67.55 & 76.54 \\
Ratio NSC:RDP & - & - & 4.05 & 3.14 & 2.71 & 2.29 \\
\hline
\end{tabular}

\footnotetext{
${ }^{1}$ Extrapolated from large breed growing heifers gaining $0.80 \mathrm{~kg} / \mathrm{d}$ (NRC, 1989).

${ }^{2}$ Inputs into table generator for heifers were: mature BW $650 \mathrm{~kg}$, BW $180 \mathrm{~kg}$, ADG $800 \mathrm{~g} / \mathrm{d}$, BCS 2.82 , age $6.5 \mathrm{mo}$, and days pregnant 0 (NRC, 2001).

${ }^{3} \mathrm{NRC}$ (2001) CP intake requirement (from the heifer requirement table generator), is the sum of RDP and RUP when perfectly balanced.

${ }^{4}$ Estimated: Metabolizable energy $(\mathrm{ME})=\mathrm{TDN} * 0.04409 * 0.82$.

${ }^{5} \mathrm{~g}$ of $\mathrm{CP}$ per Mcal of ME.

${ }^{6}$ Ratio of nonstructural carbohydrates to RDP, g of NSC per g of RDP.
}

quirements provided by the heifer requirement table generator (NRC, 2001). By design, daily CP intake increased with the increased CP concentration of the treatment ration. Metabolizable energy intake remained constant across treatment rations. Calculated CP:ME ratios of the treatment rations were 48.3, 59.1, 67.5, and $76.5 \mathrm{~g}$ of CP per Mcal ME.

Casper et al. (1994) emphasized synchronization of the NSC:RDP ratio is critical for young growing heifers because of limitations in DMI and fermentation capacity. Casper et al. (1994) goes on to state synchronizing NSC:RDP ratios may increase AA flow to the small intestine through increased microbial protein synthesis and efficiency of rumen fermentation, thus maximizing the efficiency of CP toward growth. In the current study, heifers were fed NSC:RDP ratios (Table 3; g of NSC per $\mathrm{g}$ of RDP) of 4.05 for the $48.2 \mathrm{CP}$ :ME ratio, 3.14 for the 59.1 CP:ME ratio, 2.71 for the $67.5 \mathrm{CP}: \mathrm{ME}$ ratio, and 2.29 for $76.6 \mathrm{CP}: \mathrm{ME}$ ratio.

Oldham (1984) states the interrelationship between protein and energy-yielding nutrients within the rumen and within the ruminant body can have tremendous effects on the overall pattern of nutrient use. Consequently, the relative amounts of protein and energy supplied to the animal are likely to determine net efficiency of the absorbed nutrients. Efficiency of feed conversion to BW gain is a measure of nutrient use. Feed efficiency (Table 2) improved linearly with increasing CP:ME ratios. This is in agreement with Veira et al. (1980), Bagg et al. (1985), and Lammers and Heinrichs (2000), who reported maximum $\mathrm{FE}$ at a CP:ME ratio of approximately $60 \mathrm{~g}$ of $\mathrm{CP}$ per Mcal ME. However, these studies reported rates of gain of $0.90 \mathrm{~kg} / \mathrm{d}$ and higher. On average, a $7.1 \%$ reduction in $\mathrm{FE}$ resulted between the $48.3 \mathrm{CP}: \mathrm{ME}$ ratio and the remaining
CP:ME ratios of 59.1, 67.5, and 76.5 in the current study. The low CP intake of the $48.3 \mathrm{CP}: \mathrm{ME}$ ratio, 397 $\mathrm{g} / \mathrm{d}$, in comparison to NRC (2001) recommendations of $710.4 \mathrm{~g}$ of $\mathrm{CP} / \mathrm{d}$ when RDP and RUP are perfectly balanced, possibly accounts for the high FE.

The linearly improved FE with increased CP:ME ratios may also be the result of linearly decreasing NSC:RDP ratios. Hoover and Stokes (1991) summarized data from several lactating cow studies indicating that decreasing NSC:RDP ratios increased quantity of microbial protein synthesized resulting in improved nutrient utilization. Casper et al. (1994) reported increased ADG of Holstein heifers (150 kg BW) consuming the lowest NSC:RDP ratio, 3.30. In the current study, FE linearly improved with linearly decreasing NSC:RDP ratios $(4.05,3.14,2.71$, and 2.29 , respectively), particularly starting at the $3.14 \mathrm{NSC}$ :RDP ratio for 59.1 CP:ME ratio.

Plasma urea $\mathrm{N}$ levels (Table 2) were linearly increased with increasing ratios of CP:ME. These results agree with Hall et al. (1995) who reported that PUN is related to $\mathrm{CP}$ intake in beef heifers. McShane et al. (1989) states that the PUN level may also be influenced by the energy availability of the diet. Because treatment rations were similar in total NSC and DMI as a percentage of BW remained constant across treatment rations, the increased PUN values with increasing ratios of $\mathrm{CP}: \mathrm{ME}$, is the result of increased intakes of $\mathrm{CP}$ or specific CP fractions.

Structural growth was evaluated by measuring wither height, hip height, hip width, and heart girth every $28 \mathrm{~d}$ (Table 4). Increased ratios of CP:ME resulted in trends toward linear increases in change of wither and hip height. Structural growth results agree with Lammers and Heinrichs (2000); however, Lammers and 
Table 4. Least square means for structural growth measurements and BCS of Holstein heifers fed increasing ratios of dietary CP to metabolizable energy from 125 to $234 \mathrm{~kg}$ of BW.

\begin{tabular}{|c|c|c|c|c|c|c|c|c|}
\hline & \multicolumn{4}{|c|}{$\begin{array}{c}\text { Dietary CP to metabolizable energy ratios } \\
\text { (g CP per Mcal ME) }\end{array}$} & \multirow[b]{2}{*}{$\mathrm{SE}$} & \multicolumn{3}{|c|}{ Contrast $(P)$} \\
\hline & 48.3 & 59.1 & 67.5 & 76.5 & & Linear & Quadratic & Cubic \\
\hline \multicolumn{9}{|l|}{ Wither height } \\
\hline Initial, cm & 95.55 & 95.80 & 95.59 & 95.37 & 0.82 & 0.84 & 0.77 & 0.90 \\
\hline Final, cm & 112.27 & 112.06 & 112.78 & 114.01 & 0.91 & 0.15 & 0.44 & 0.92 \\
\hline Change, $\mathrm{cm} / \mathrm{d}$ & 0.12 & 0.12 & 0.13 & 0.13 & 0.01 & 0.09 & 0.40 & 0.71 \\
\hline \multicolumn{9}{|l|}{ Hip height } \\
\hline Initial, $\mathrm{cm}$ & 99.57 & 99.32 & 99.65 & 99.10 & 0.75 & 0.75 & 0.85 & 0.66 \\
\hline Final, cm & 116.00 & 116.42 & 116.12 & 118.03 & 0.97 & 0.19 & 0.45 & 0.50 \\
\hline Change, $\mathrm{cm} / \mathrm{d}$ & 0.12 & 0.12 & 0.13 & 0.13 & 0.01 & 0.10 & 0.98 & 0.77 \\
\hline \multicolumn{9}{|l|}{ Hip width } \\
\hline Initial, $\mathrm{cm}$ & 27.56 & 27.60 & 27.86 & 27.35 & 0.31 & 0.78 & 0.39 & 0.49 \\
\hline Final, cm & 35.18 & 35.82 & 36.03 & 34.91 & 0.46 & 0.77 & 0.06 & 0.66 \\
\hline Change, $\mathrm{cm} / \mathrm{d}$ & 0.06 & 0.06 & 0.06 & 0.05 & 0.01 & 0.59 & 0.05 & 0.47 \\
\hline \multicolumn{9}{|l|}{ Heart girth } \\
\hline Initial, $\mathrm{cm}$ & 112.35 & 112.48 & 113.46 & 112.02 & 1.13 & 0.99 & 0.49 & 0.52 \\
\hline Final, cm & 137.17 & 138.94 & 138.73 & 137.25 & 1.42 & 0.99 & 0.26 & 0.91 \\
\hline Change, $\mathrm{cm} / \mathrm{d}$ & 0.18 & 0.19 & 0.18 & 0.18 & 0.01 & 0.84 & 0.24 & 0.81 \\
\hline \multicolumn{9}{|l|}{$\mathrm{BCS}$} \\
\hline Initial & 2.58 & 2.59 & 2.61 & 2.60 & 0.03 & 0.52 & 0.63 & 0.69 \\
\hline Final & 2.97 & 2.98 & 2.96 & 2.92 & 0.03 & 0.32 & 0.34 & 0.98 \\
\hline Change $^{1}$ & 0.38 & 0.38 & 0.37 & 0.32 & 0.01 & 0.27 & 0.13 & 0.58 \\
\hline
\end{tabular}

${ }^{1}$ Change in BCS (five-point score where 1 = under-conditioned and $5=$ over- conditioned) from the beginning until the end of the trial.

Heinrichs (2000) did not restrict ADG, as was done in the present study, and as a consequence reported greater treatment differences. Increasing linear trends in wither and hip height growth with increasing CP:ME ratios might be explained by decreasing NSC:RDP ratios. Casper et al. (1994) reported increased ADG with the lowest NSC:RDP ratio of 3.30 and hypothesized synchronizing NSC:RDP ratios may increase AA flow to the small intestine, and maximize the efficiency protein is used toward growth.

Hip width growth (Table 4) showed a quadratic effect. Heifers receiving the CP:ME ratios of 48.3, 59.1, and 67.5 possessed an 8.0, 8.7, and 8.8\% greater hip width growth than the 76.5 CP:ME ratio. Lammers and Heinrichs (2000) showed linear increases in hip width growth with increasing CP:ME ratios, which is in disagreement with the present study's results. The disparity between studies may be the result of restricting ADG. Heart girth growth and change in BCS were not different for increasing CP:ME ratios. Final measurements of these parameters were also not different.

\section{CONCLUSIONS}

Based on a feeding trial utilizing 60 prepubertal Holstein heifers between 125 to $234 \mathrm{~kg}$ BW restricted feed to gain $0.80 \mathrm{~kg} / \mathrm{d}$, a diet CP:ME ratio of 48.3 performed poorly in comparison to CP:ME ratios of 59.1, 67.5, and 76.5 when one considers the linear effects of $\mathrm{FE}$ and structural growth from the present study. Prepubertal Holstein heifers consuming diets containing CP:ME ratios of 59.1, 67.5, and 76.5 showed improved FE and some structural growth measurements. However, a quadratic effect for DMI and high PUN concentrations indicate CP:ME ratios should be below 76.5 and within the CP:ME range of 48.3 to 76.5 for dairy heifers between 125 and $234 \mathrm{~kg}$ BW consuming 2.0\% DMI as BW and gaining $0.80 \mathrm{~kg} / \mathrm{d}$ to achieve improved feed efficiency and increased structural growth. Linear decreases in ratios of NSC:RDP of treatment rations may have increased RDP utilization and maximized the efficiency that protein was used toward growth.

\section{ACKNOWLEDGMENTS}

The authors wish to thank Maria Long, Trent Schriefer, Keith Leismeister, Todd Morris, Tim Haltman, and Gabe Mignot for laboratory and technical assistance.

\section{REFERENCES}

Association of Official Analytical Chemists. 1990. Official Methods of Analysis. 15th ed. AOAC, Arlington, VA.

Bagg, J. G., D. G. Grieve, J. H. Burtone, and J. B. Stone. 1985. Effect of protein on growth of Holstein heifer calves from 2 to 10 months. J. Dairy Sci. 68:2929-2939.

Casper, D. P., D. J. Schingoethe, M. J. Brouk, and H. A. Maiga. 1994. Nonstructural carbohydrates and undegradable protein sources 
in the diet: Growth responses of dairy heifers. J. Dairy Sci. 77:2595-2604.

Dubois, M., K. A. Gilles, J. K. Hamilton, P. A. Rebers, and F. Smith. 1956. Colorimetric method for determination of sugars and related substances. Anal. Chem. 28:350.

Hall, J. B., R. B. Staigmiller, R. A. Bellows, R. E. Short, W. M. Mosely, and S. E. Bellows. 1995. Body composition and metabolic profiles associated with puberty in beef heifers. J. Anim. Sci. 73:34093420 .

Holm, J., B. A. Drews, and N. G. Asp. 1986. A rapid method for the analysis of starch. Starch/die starke. 7:224-226.

Hoover, W. H., and S. R. Stokes. 1991. Balancing carbohydrate and protein for optimum rumen microbial yield. J. Dairy Sci. 74:3630-3644.

Kertz, P. F., L. R. Prewitt, and J. M. Ballam. 1987. Increased weight gain and effects on growth parameters of Holstein heifer calves from 3 to 12 months of age. J. Dairy Sci. 70:1612-1622.

Krishnamoorthy, U., T. V. Muscato, C. J. Sniffen, and P. J. Van Soest. 1982. Nitrogen fractions in selected feedstuffs. J. Dairy Sci. 65:217-225.

Krishnamoorthy, U., C. J. Sniffen, M. D. Stern, and P. J. Van Soest. 1983. Evaluation of a mathematical model of rumen digestion and an in vivo simulation of rumen proteolysis to estimate rumen undegradable nitrogen content of feedstuffs. Br. J. Nutr. 50:55-63.

Lammers, B. P., D. R. Buckmaster, and A. J. Heinrichs. 1996. A simple method for the analysis of particle sizes of forage and total mixed rations. J. Dairy Sci. 79:922-928.

Lammers, B. P., A. J. Heinrichs, and R. S. Kensinger. 1999. The effects of accelerated growth rates and estrogen implants in prepubertal Holstein heifers on estimates of mammary development and subsequent reproduction and milk production. J. Dairy Sci. 82:1753-1764.

Lammers, B. P., and A. J. Heinrichs. 2000. The response of altering the ratio of dietary protein to energy on growth, feed efficiency, and mammary development in rapidly growing prepubertal heifers. J. Dairy Sci. 83:977-983.

Littell, R. C., G. A. Milliken, W. W. Stroup, and R. D. Wolfinger. 1996. SAS System for mixed models. SAS Inst., Inc., Cary, NC.

McShane, T. M., K. K. Schillo, M. J. Estienne, J. A. Boling, N. W. Bradley, and J. B. Hall. 1989. Effects of recombinant DNA-derived somatotropin and dietary energy intake on development of beef heifers: II. Concentrations of hormones and metabolites in blood sera. J. Anim. Sci. 67:2237-2244.

Meinert, R. A., C.-M. J. Yang, A. J. Heinrichs, and G. A. Varga. 1992. Effect of Monensin on growth, reproductive performance, and estimated body composition of Holstein heifers. J. Dairy Sci. 75:257-261.

National Research Council. 1996. Nutrient requirements of beef cattle. 7th Rev. ed. Natl. Acad. Sci., Washington, DC.

National Research Council. 1989. Nutrient requirements of dairy cattle. 6th rev. ed. Natl. Acad. Sci., Washington, DC.

National Research Council. 2001. Nutrient requirements of dairy cattle. 7th rev. ed. Natl. Acad. Sci., Washington, DC.

Oldham, J. D. 1984. Protein-energy interrelationships in dairy cows. J. Dairy Sci. 67:1090-1114.

Preston, R. L. 1966. Protein requirements of growing-finishing cattle and lambs. J. Nutr. 90:157-160.

Radcliff, R. P., M. J. Vandehaar, A. L. Skidmore, L. T. Chapin, B. R. Radke, J. W. Lloyd, E. P. Stanisiewski, and H. A. Tucker. 1997. Effect of diet and bovine somatropin on heifer growth and mammary development. J. Dairy Sci. 80:1996-2003.

SAS User's Guide: Statistics, Version 5th Edition. 1985. SAS Inst., Inc., Cary, NC.

Schurman, E. W., and E. M. Kesler. 1974. Protein-to-energy ratios in complete feeds for calves at ages 8 to 18 weeks. J. Dairy Sci. 57:1381-1384.

Smith, D. 1981. Removing and analyzing carbohydrates from plant tissues. Wisconsin Agric. Exp. Stn. Rep. No. R2107, Madison, WI.

Swartz, L. A., A. J. Heinrichs, G. A. Varga, and L. D. Muller. 1991. Effects of varying dietary undegradable protein on dry matter intake, growth, carcass composition of Holstein calves. J. Dairy Sci. 74:3884-3890.

Van Amburgh, M. E., D. M. Galton, D. E. Bauman, R. W. Everett, D. G. Fox, L. E. Chase, and H. N. Erb. 1998. Effects of three prepubertal body growth rates on performance of Holstein heifers during first lactation. J. Dairy Sci. 81:527-538.

Veira, D. M., G. K. Macleod, J. H. Burton, and J. B. Stone. 1980. Nutrition of the weaned Holstein calf. II. Effect of dietary protein level on nitrogen balance, digestibility, and feed intake. J. Anim. Sci. 50:945-951. 